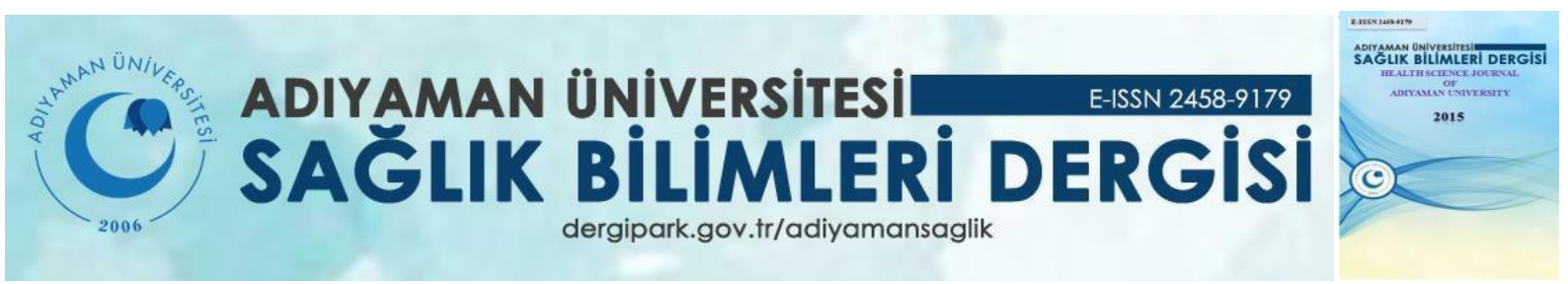

Araştırma/Research

\title{
Dermatoloji Eğitiminde Vakaya Dayalı Öğrenme: Bir Geri Bildirim Modeli
}

\section{Nihal Altunışık ${ }^{1}$, Dursun Türkmen², Serpil Şener³, Burcu Kayhan Tetik ${ }^{4}$, Harika Gözükara Bağ ${ }^{5}$}

${ }^{1}$ Dr. Öğr. Üyesi, İnönü Üniversitesi Tıp Fakültesi, Dermatoloji Anabilim Dalı, Malatya Türkiye ORCID: 0000-0001-6844-1097

${ }^{2}$ Dr. Öğr. Üyesi, İnönü Üniversitesi Tıp Fakültesi, Dermatoloji Anabilim Dalı, Malatya Türkiye ORCID: 0000-0001-90764669

${ }^{3}$ Doç. Dr, İnönü Üniversitesi Tıp Fakültesi, Dermatoloji Anabilim Dalı, Malatya Türkiye ORCID: 0000-0002-7012-2666

\section{ÖZ}

Amaç: Deri hastalıklarının çoğu öncelikle birinci basamak sağlık kuruluşlarındaki hekimler tarafından görüldüğü için öğrencilik döneminde verilen dermatoloji eğitimi sık sık güncellenmelidir. Vakaya dayalı öğrenme modelinde bilginin belli bir olguya odaklandırılarak gözden geçirilmesi hedeflenir. Çalışmamızda üniversitemizdeki ögrencilere verilen dermatoloji stajı eğitiminin yeterlilik düzeyinin değerlendirilmesi ve vakaya dayalı öğrenme metodunun öğrenci eğitimine katkısının değerlendirilmesi amaçlanmıştır.

Gereç ve Yöntem: İnönü Üniversitesi Tıp Fakültesi’nde eğitim gören 47 altıncı sınıf öğrencisi çalışmaya dahil edildi. Eğitim öncesi öğrencilere birinci basamak sağlık kuruluşlarında en sık rastlanan hastalıklardan seçilen 10 vaka resmi (sırasıyla pedikülozis kapitis, tinea kapitis, herpes genitalis, tinea fasiyalis, erizipel, zona zoster, viral siğil, ürtiker, seboreik dermatit ve atopik dermatit) gösterildi. Her resim için tanı ve tedavi cevaplarının yazılabileceği boş alanlar içeren açık uçlu anketler dağıtıldı. Cevaplar toplandıktan sonra resimlerdeki vakaların tanı ve tedavileri anlatıldı. Eğitim tamamlandıktan sonra anketler tekrarlandı.

Bulgular: Eğitim öncesi ve sonrası tanıya yönelik verilen cevaplar karşılaştırıldığında iki, dört, beş, yedi ve sekizinci sorularda istatistiksel olarak anlamlı fark bulundu $(\mathrm{p}<0,05)$. Eğitim öncesi ve sonrası tedaviye yönelik verilen cevaplar karşılaştırıldığında bir, üç, dört, altı, yedi ve sekizinci sorularda istatistiksel olarak anlamlı fark tespit edildi $(\mathrm{p}<0,05)$.

Sonuç: Çalışmamızda vaka görselleri üzerinden yapılan eğitimde doğru tanı oranlarının eğitim öncesine göre belirgin olarak arttığı tespit edildi. Bu sonuç dermatoloji stajında vaka temelli eğitimin önemini göstermektedir.

Anahtar kelimeler: Dermatoloji; vakaya dayalı eğitim; tıp eğitimi

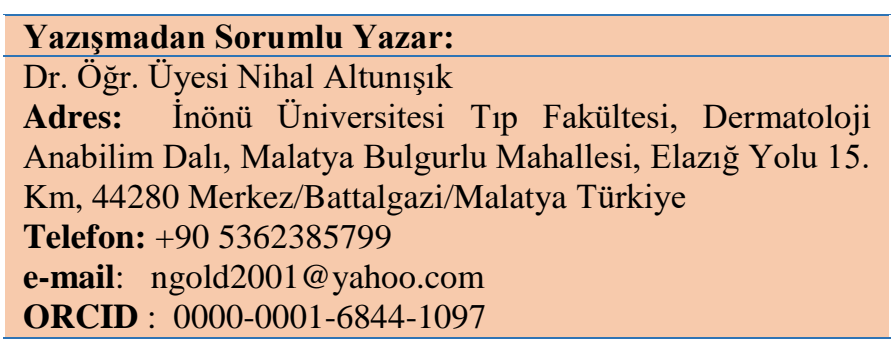

Doi: 10.30569.adiyamansaglik.635840

Atıf Gösterimi/How to Cite: Altunışık N, Türkmen D, Şener S, Kayhan Tetik B, Gözükara Bağ H. Dermatoloji Eğitiminde Vakaya Dayalı Öğrenme: Bir Geri Bildirim Modeli. Adıyaman Üni. Sağlık Bilimleri Derg. 2019; 5(3);1807-1813. doi:10.30569.adiyamansaglik.635840
Geliş Tarihi : 22.10.2019

Kabul Tarihi : 14.12.2019 


\section{Case Based Learning in Dermatology Education: A Feedback Model}

\section{ABSTRACT}

Objective: Since most of the skin diseases are seen primarily by physicians in primary health care institutions, dermatology training given during the student period should be updated frequently. The case-based learning model aims to review information by focusing on a particular case. The aim of this study was to evaluate the proficiency level of dermatology internship education given to students in our university and to evaluate the contribution of casebased learning method to student education.

Materials and Methods: Forty seven sixth grade students studying at İnönü University Faculty of Medicine were included in the study. Before the training, 10 case pictures (pediculosis capitis, tinea capitis, herpes genitalis, tinea facialis, erysipelas, zona zoster, viral wart, urticaria, seborrheic dermatitis and atopic dermatitis) were shown to the students. Open-ended questionnaires were distributed for each picture with blank spaces for diagnosis and treatment responses. After the answers were collected, the diagnosis and treatment of the cases were explained. After the training was completed, the questionnaires were repeated.

Results: When the answers given before and after education were compared, a statistically significant difference was found in the questions two, four, five, seven and eight $(p<0.05)$. When the answers given before and after the training were compared, a statistically significant difference was found in the questions one, three, four, six, seven and eight ( $p<0.05)$.

Conclusion: In our study, it was found that accurate diagnosis rates increased significantly when compared with pre-training in case-based education. This result shows the importance of case based education in dermatology internship.

Key words: Dermatology; case-based education; medical education.

\section{GIRIŞ}

Tıp eğitimi tüm eğitimler içinde oldukça özel bir yere sahiptir. Genel toplumun sağlıklılık halini düzenleyerek ülkelerin gelişmişlik düzeyine etki eden mesleğin mensuplarını yetiştirmek oldukça önemlidir. Gün geçtikçe tıp alanında ortaya çıkan yeni gelişmeler de dikkate alındığında tıp fakültelerinin eğitim şekillerinin sık sık güncellenmesi gerekmektedir. Eğitimde amaç, bilginin en kısa sürede en yüksek düzeyde aktarılması ve pratik hayatta nasıl kullanılacağının öğretilmesidir (1). 
Dermatoloji terminolojisinin ve hasta yaklaşımının diğer bölümlere göre farklılık göstermesi nedeniyle etkili bir eğitimin nasıl olması gerektiği konusunda literatürde çeşitli çalışmalar bulunmaktadır. Deri hastalıklarının çoğu öncelikle birinci basamak sağlık kuruluşlarındaki hekimler tarafından görüldüğü için öğrencilik döneminde verilen dermatoloji eğitiminin yeterli olması çok önemlidir. Özellikle teorik açıdan yoğun bilgi içeren dermatoloji eğitiminin nasıl olması gerektiği tartışmalı bir konudur $(2,3)$.

Tıp eğitiminde çeşitli eğitim sistemleri mevcuttur. Klasik sistemde bir hekimin kazanması gereken bilgi ve beceriler ilgili bölümlerde konular belli bir sıralama içerisinde anlatılır. Entegre sistemde eğitim bileşenleri, zaman sıralamasına göre kendinden önceki bileşeni destekler veya sonrakiler için zemin oluşturur. Böylece bütünsel bir öğrenme sağlanır. Öğrencinin aktif konuma geçtiği probleme dayalı eğitimde öğrenciler, meslek hayatlarında karşılaşabilecekleri durumların benzerleriyle karşı karşıya getirilmektedir. Vakaya dayalı öğrenme modelinde bilginin belli bir olguya odaklandırılarak gözden geçirilmesi hedeflenir. Bu yöntemde, her bir gruba rehberlik eden eğitimcilerle birlikte öğrenciler küçük gruplara bölünür. Probleme dayalı öğrenme ve vakaya dayalı öğrenme tartışmaya dayanan küçük gruplu öğrenme metodlarıdir $(1,4,5)$.

Çalışmamızda hem üniversitemizde eğitim gören altıncı sınıf öğrencilerine bir önceki yıl verilen dermatoloji stajı eğitiminin yeterlilik düzeyinin değerlendirilmesi hem de vakaya dayalı öğrenme metodunun öğrenci eğitimine katkısının değerlendirilmesi amaçlanmıştır.

\section{GEREÇ VE YÖNTEM}

Çalışmaya İnönü Üniversitesi Tıp Fakültesi'nde eğitim gören altıncı sınıf öğrencilerinden sözlü olarak çalışmaya katılmayı kabul edenler dâhil edildi. Altıncı sınıf öğrencilerinin eğitimden önceki ve sonraki başarı durumlarını $\% 95$ güven düzeyinde $(\alpha=0,05)$ ve $\% 80$ güç $(\beta=0,20)$ ile karşılaştırmak için aradaki farkın 0,25 olacağı öngörüsü ile çalışmaya alınması gereken minimum örnek sayısı 32 olarak hesaplanmıştır. Ağustos- Eylül 2019 tarihleri arasında İnönü Üniversitesi Tıp Fakültesi Aile Hekimliği Anabilim Dalında eğitim gören 47 dönem altı öğrencisi dahil edildi. Öğrenciler kendi içinde küçük gruplara bölündü. Eğitim öncesi öğrencilere birinci basamak sağlık kuruluşlarında en sık rastlanan hastalıklardan seçilen 10 vaka resmi (sırasıyla pedikülozis kapitis, tinea kapitis, herpes genitalis, tinea fasiyalis, erizipel, zona zoster, viral siğil, ürtiker, seboreik dermatit ve atopik dermatit) gösterildi. Her resim için tanı ve tedavi cevaplarının yazılabileceği boş alanlar içeren açık uçlu anketler dağıtıldı. 
Cevaplar toplandıktan sonra resimlerdeki vakaların tanı ve tedavileri anlatıldı. Eğitim tamamlandiktan sonra anketler tekrarland1.

Çalışma Helsinki Deklarasyonu'na uygun olarak gerçekleştirildi. Çalışma için yerel etik kurulu onayı alındı. İstatistiksel değerlendirmede SPSS (SPSS for Windows, Version 17.0, SPSS Inc, ABD) paket programı kullanıldı. Nitel değişkenlere ait veriler sayı ve yüzde olarak, nicel değişkenlere ait veriler ise ortalama \pm SS olarak belirtildi. Kategorik değişkenlerin karşılaştırılması için ki-kare testi kullanıldı ve p<0,05 değeri anlamlı olarak kabul edildi.

\section{BULGULAR}

Çalışmaya 47 dönem altı öğrencisi dahil edildi. Öğrencilerin eğitim öncesi ve sonrası tanıya yönelik anket sonuçları Tablo 1'de gösterilmiştir. Eğitimden önce sorulara sırasıyla verilen doğru cevap sayıları, 40 (\% 85,1), 30 (\% 63,8), 34 (\% 72,3), 14 (\% 29,8), 25 (\% 53,2), 42 (\% 89,4), $20(\% 42,6), 30(\% 63,8), 42(\% 89,4), 37$ (\% 78,7), eğitimden sonra ise $42(\% 89,4), 41$ (\% 87,2), 38 (\% 80,9), 29 (\% 61,7), 38 (\% 80,9), 46 (\% 97,9), 33 (\% 70,2), 45 (\% 95,7), 43 (\% 91,5), 44 (\% 93,6) olarak tespit edildi. Eğitim öncesi ve sonrası cevaplar karşılaştırıldığında iki, dört, beş, yedi ve sekizinci sorularda istatistiksel olarak anlanlı fark bulundu $(p<0,05)$.

Tablo 1. Öğrencilerin eğitim öncesi ve sonrası tanıya yönelik anket sonuçları

\begin{tabular}{|c|c|c|c|c|c|}
\hline \multirow[b]{2}{*}{ Sorular } & \multicolumn{2}{|c|}{ Doğru cevap n(\%) } & \multicolumn{2}{|c|}{ Yanlış cevap n(\%) } & \multirow[b]{2}{*}{$\mathrm{P}$ değeri } \\
\hline & $\begin{array}{l}\text { Eğitimden } \\
\text { önce }\end{array}$ & $\begin{array}{l}\text { Eğitimden } \\
\text { sonra }\end{array}$ & $\begin{array}{l}\text { Eğitimden } \\
\text { önce }\end{array}$ & $\begin{array}{l}\text { Eğitimden } \\
\text { sonra }\end{array}$ & \\
\hline $\begin{array}{c}\text { Soru 1 } \\
\text { (Pedikülozis kapitis) }\end{array}$ & $40(85,1)$ & $42(89,4)$ & $7(14,8)$ & $5(10,6)$ & 0,75 \\
\hline $\begin{array}{c}\text { Soru 2 } \\
\text { (Tinea kapitis) } \\
\end{array}$ & $30(63,8)$ & $41(87,2)$ & $17(36,2)$ & $6(12,8)$ & 0,016 \\
\hline $\begin{array}{c}\text { Soru 3 } \\
\text { (Herpes genitalis) }\end{array}$ & $34(72,3)$ & $38(80,9)$ & $13(27,7)$ & $9(19,1)$ & 0,46 \\
\hline $\begin{array}{c}\text { Soru } 4 \\
\text { (Tinea fasiyalis) } \\
\end{array}$ & $14(29,8)$ & $29(61,7)$ & $33(70,2)$ & $18(38,3)$ & 0,004 \\
\hline $\begin{array}{c}\text { Soru 5 } \\
\text { (Erizipel) }\end{array}$ & $25(53,2)$ & $38(80,9)$ & $22(44,8)$ & $9(19,1)$ & 0,008 \\
\hline $\begin{array}{c}\text { Soru 6 } \\
\text { (Zona zoster) }\end{array}$ & $42(89,4)$ & $46(97,9)$ & $5(10,6)$ & $1(2,1)$ & 0,20 \\
\hline $\begin{array}{c}\text { Soru } 7 \\
\text { (Viral siğil) } \\
\end{array}$ & $20(42,6)$ & $33(70,2)$ & $27(57,4)$ & $14(29,8)$ & $\mathbf{0 , 0 1 3}$ \\
\hline $\begin{array}{c}\text { Soru } 8 \\
\text { (Ürtiker) }\end{array}$ & $30(63,8)$ & $45(95,7)$ & $17(36,2)$ & $2(4,3)$ & $<0,001$ \\
\hline $\begin{array}{c}\text { Soru } 9 \\
\text { (Seboreik dermatit) }\end{array}$ & $42(89,4)$ & $43(91,5)$ & $5(10,6)$ & $4(8,5)$ & 1,00 \\
\hline $\begin{array}{c}\text { Soru 10 } \\
\text { (Atopik dermatit) } \\
\end{array}$ & $37(78,7)$ & $44(93,6)$ & $10(21,3)$ & $3(6,4)$ & 0,073 \\
\hline
\end{tabular}


Öğrencilerin eğitim öncesi ve sonrası tedaviye yönelik anket sonuçları Tablo 2'de verilmiştir. Eğitimden önce sorulara sırasıyla verilen doğru cevap sayıları, bir (\% 2,1), sıfır (\% 0), yedi (\% 1,4), bir (\% 2,1), $11(\%$ 23,4), altı (\% 12,7), 14 (\% 29,7), üç (\% 6,3), dokuz (\% 19,1), 29 (\% 61,7), eğitimden sonra ise 11 (\% 23,4), bir (\% 2,1), 23 (\% 48,9), dokuz (\% 19,1), $21(\% 44,6)$, 20 (\% 42,5), 36 (\% 76,5), 11 (\% 23,4), 13 (\% 27,6), 38 (\% 80,8) olarak saptandı. Eğitim öncesi ve sonrası cevaplar karşılaştırıldığında bir, üç, dört, altı, yedi ve sekizinci sorularda istatistiksel olarak anlamli fark tespit edildi $(\mathrm{p}<0,05)$.

Tablo 2. Öğrencilerin eğitim öncesi ve sonrası tedaviye yönelik anket sonuçları

\begin{tabular}{|c|c|c|c|c|c|}
\hline \multirow[b]{2}{*}{ Sorular } & \multicolumn{2}{|c|}{ Doğru cevap n(\%) } & \multicolumn{2}{|c|}{ Yanlış cevap n(\%) } & \multirow[b]{2}{*}{$\mathrm{P}$ değeri } \\
\hline & $\begin{array}{l}\text { Eğitimden } \\
\text { önce }\end{array}$ & $\begin{array}{l}\text { Eğitimden } \\
\text { sonra }\end{array}$ & $\begin{array}{l}\text { Eğitimden } \\
\text { önce }\end{array}$ & $\begin{array}{l}\text { Eğitimden } \\
\text { sonra }\end{array}$ & \\
\hline $\begin{array}{c}\text { Soru 1 } \\
\text { (Pedikülozis kapitis) }\end{array}$ & $1(2,1)$ & $11(23,4)$ & $46(97,9)$ & $36(76,6)$ & 0,005 \\
\hline $\begin{array}{c}\text { Soru 2 } \\
\text { (Tinea kapitis) } \\
\end{array}$ & $0(0)$ & $1(2,1)$ & $47(100)$ & $46(97,9)$ & 1,00 \\
\hline $\begin{array}{c}\text { Soru 3 } \\
\text { (Herpes genitalis) }\end{array}$ & $7(1,4)$ & $23(48,9)$ & $40(98,6)$ & $24(51,1)$ & 0,001 \\
\hline $\begin{array}{c}\text { Soru } 4 \\
\text { (Tinea fasiyalis) } \\
\end{array}$ & $1(2,1)$ & $9(19,1)$ & $46(97,9)$ & $38(80,9)$ & 0.019 \\
\hline $\begin{array}{c}\text { Soru 5 } \\
\text { (Erizipel) }\end{array}$ & $11(23,4)$ & $21(44,6)$ & $36(76,6)$ & $26(55,4)$ & 0,05 \\
\hline $\begin{array}{c}\text { Soru } 6 \\
\text { (Zona zoster) }\end{array}$ & $6(12,7)$ & $20(42,5)$ & $41(87,3)$ & $27(57,5)$ & $\mathbf{0 , 0 0 3}$ \\
\hline $\begin{array}{c}\text { Soru } 7 \\
\text { (Viral siğil) } \\
\end{array}$ & $14(29,7)$ & $36(76,5)$ & $33(70,3)$ & $11(23,5)$ & $<0,001$ \\
\hline $\begin{array}{c}\text { Soru 8 } \\
\text { (Ürtiker) } \\
\end{array}$ & $3(6,3)$ & $11(23,4)$ & $44(93,7)$ & $36(76,6)$ & 0,043 \\
\hline $\begin{array}{c}\text { Soru } 9 \\
\text { (Seboreik dermatit) }\end{array}$ & $9(19,1)$ & $13(27,6)$ & $38(80,9)$ & $34(72,4)$ & 0,46 \\
\hline $\begin{array}{c}\text { Soru 10 } \\
\text { (Atopik dermatit) }\end{array}$ & $29(61,7)$ & $38(80,8)$ & $18(38,3)$ & $9(19,2)$ & 0,72 \\
\hline
\end{tabular}

\section{TARTIŞMA}

Dermatolojik rahatsızlıklar gün geçtikçe çoğalan sağlık problemlerindendir ve günümüzde cilt hastalıkları olan hasta sayısı giderek artmaktadır. Dermatoloji eğitiminin temel amacı, öğrencilere mezuniyet sonrası gerekli olan beceri ve yetkinlikleri kazanmalarını sağlamaktır. $\mathrm{Bu}$ nedenle tıp fakültesi mezunlarının gerekli klinik yeterlilikte olmaları için, fakültelerin müfredatlarını ve eğitim sistemlerini belli aralıklarla gözden geçirmeleri gerekmektedir (6). 
Kanada'da yapılan bir çalışmada 2008 ve 2017 yılları arasında 17 tıp fakültesinde dermatoloji eğitimi elektronik anket yoluyla değerlendirilmiştir. Çalışma sonucunda Kanada'da tıp fakültelerinde dermatoloji eğitim saatlerinin arttığı fakat yaklaşık \% 75 'inin preklinik dönemde olduğu, günümüzde giderek artan sayıda okulda elektronik öğretim formatlarını kullandığı ve çoğu okulun çekirdek müfredat konularını kapsadığı tespit edilmiştir (7).

Farklı ülkelerde tıp fakültelerinde dermatoloji öğretimi için ayrılan süreler büyük farklılıklar göstermektedir. Bununla birlikte aynı ülke içerisindeki fakülteler arasında da eğitim sitemi farklılıkları görülebilmektedir. Örneğin Kanada'da, dermatoloji eğitimi için ortalama 20,5 saate izin veren bir tıp fakültesi olduğu gibi, aynı ülkede diğer okullarda sadece dört saate izin verildiği tespit edilmiştir (6).

Türkiye'de, tıp fakültelerinde Deri ve Zührevi Hastalıklar eğitimi dönem beş öğrencilerine verilmektedir. Bu süre genellikle üç hafta ya da bir ay gibi kısa bir süreçtir. Staj boyunca öğrencilere hem teorik eğitim uygulanmakta hem de poliklinik, yataklı hasta servisinde ve müdahale ünitelerinde pratik uygulamalar yaptırılmaktadır. Ancak staj bittikten sonra ilerleyen süreçte genellikle ek bir eğitim programı yer almamaktadır. Bu nedenle staj süresinde verilen eğitimin mümkün oldukça birinci basamak sağlık kuruluşlarına başvuran hastalarda en sık rastlanan dermatolojik tanılara ve bu hastalıkların tedavisine yönelik olmalıdır.

Literatürde dermatoloji eğitimi ile ilgili ülkemizde yayınlanmış sınırlı sayıda çalışmaya rastlanmıştır. Aybal ve ark.'nın birinci basamak sağlık kuruluşlarında çalışan hekimlere yönelik yaptıkları anket çalışmasında en sık karşılaşılan hastalıkları ekzema, mikoz ve ürtiker olarak tanımlamışlardır. Ayrıca mezuniyet sonrası pratik yaklaşıma en fazla katkı sağlayacak eğitim etkinliklerinde intörnlükte dermatoloji eğitimine yer verilmesi ve olgu tartışmaları yüksek skor almıştır (8).

Özcan ve ark.'nın yaptıkları çalışmada dermatoloji eğitimini mezuniyet sonrası değerlendirmek için pratisyen hekimlere, dönem beş öğrencilerine dermatoloji stajı sonu sınavında uygulanan sorular sorulmuştur. Çalışmanın sonucunda pratisyen hekimlerin puan ortalaması, staj öğrencileriyle karşılaştırıldığında istatistiksel olarak anlamlı düzeyde düşük bulunmuştur (2). $\mathrm{Bu}$ çalışmalar dermatoloji eğitiminde bilgi yoğunluğundan arındırılmış ve vaka görsellerinin ağırlıkta olduğu öğretim modelleri oluşturulması gerektiğini desteklemektedir.

Dermatoloji eğitiminde vakaların klinik görünümleri önemli yer tutmaktadır. Çalışmamızda sadece hastalık görselleri üzerinden yapılan vakaya dayalı eğitimde doğru tanı oranlarının eğitim öncesine göre belirgin olarak arttığı tespit edildi. Bu sonuç dermatoloji stajında vaka 
temelli eğitimin önemini göstermektedir. Ayrıca çalışmamızda anket uygulanan öğrenciler bir y1l önce dermatoloji eğitimi almalarına rağmen eğitim öncesi bazı sorulara verilen doğru yanıt oranları düşük bulundu. Bu nedenle dönem altı öğrencilerine mezuniyet öncesi belli aralarla seminerler düzenlenmesinin eğitime katkı sağlayacağı düşüncesindeyiz.

\section{KAYNAKLAR}

1. Özcan A, Şenol M, Karaca Ş. Active education of students in Dermatology. T Klin J Dermatol 2003;13(2):95-100.

2. Özcan A, Şenol M, Karaca Ş, Kalaycı B. The evulation of dermatologic education in postgraduate period. Turkiye Klinikleri J Dermatol 2004;14(4):197-201.

3. Hartmann AC, Cruz PD. Interactive mechanisms for teaching dermatology to medical students. Arch Dermatol 1998;134(6):725-8.

4. Elçin M. Sağllk eğitiminin geldiği noktada tıp eğitiminden beklentiler. Sürekli Tip Eğitimi Dergisi 2001;10(9):338-9.

5. Srinivasan M, Wilkes M, Stevenson F, Nguyen T, Slavin S. Comparing problem-based learning with case-based learning: effects of a major curricular shift at two institutions. Acad Med 2007;82(1):74-82.

6. Al-Ghamdi HS. A novel approach to teaching dermatology and plastic surgery in a combined module for undergraduate medical students. Adv Med Educ Pract 2019;10:147-155.

7. Hu A, Vender R. Undergraduate Dermatology Education in Canada: A National Survey. J Cutan Med Surg 2018;22(1):31-7.

8. Aybal T, Güme S, Kahyaoğlu M, Kaçar N, Ergin Ş. Birinci Basamak Sağlık Kuruluşlarında Çalışan Hekimlerin Deri ve Zührevi Hastalıklar ile İlgili Deneyimleri ve Mezuniyet Öncesi Eğitim Hakkındaki Görüşleri. Türkderm 2012;46(2):67-72. 